\title{
NOTE
}

\section{Do reproduction and regeneration in damaged corals compete for energy allocation?}

\author{
B. Rinkevich \\ National Institute of Oceanography, Tel-Shikmona, PO Box 8030, Haifa 31080, Israel
}

\begin{abstract}
Several field studies have revealed that damaged corals have lower fecundity during regeneration as compared to intact colonies. This finding was interpreted as suggesting that there is a trade-off in the allocation of energy between reproductive activities versus growth and regeneration in corals, where sexual reproduction is easily disrupted. However, 3 independent lines of evidence critically challenge the paradigm of energy allocation trade-off and suggest that (1) sexual reproduction in cnidarians may not always be subject to energy constraints and may possess a hierarchial function, (2) shallow-water scleractinians may not be prone to energy constraints, and (3) regeneration is a regulated process expressed through programmed events and not directly related to the energy trade-off principle. Growth, tissue repair and the production of the germ cell require 1 major resource, the stem cells. It is suggested that any extensive use of these reserve cells may reduce their numbers and significantly affect one or more biological functions. Several studies indirectly confirm this idea. Trade-offs for stem cells between tissue repair and sexual reproduction should be considered as a relevant factor shaping reproductive activities during regeneration in reef corals.
\end{abstract}

KEY WORDS: Corals Regeneration Reproduction. Stem cells Trade-offs between traits

The paradigm. The ability to regenerate damaged tissue is a well-documented phenomenon for a variety of marine invertebrates including cnidarians that inhabit coral reefs. The capacity of coral colonies to recover lesions or repair damaged parts has attracted ecologists who have studied the consequences of regeneration on survival, growth rates, energy allocation and fitness (Meesters et al. 1992, 1994, Meesters \& Bak 1993, Van Veghel \& Bak 1994, Ward 1995, Kramarsky-Winter \& Loya 1996 and literature therein).

Available energy is often limited and must be divided between several biological functions, such as repair, maintenance, reproduction and somatic growth. One important facet of this general idea is the concept of optimizing energy allocation to reproduction during different stages of the animal's life (Kozlowski \& Wiegert 1986). Although growth, maintenance and repair are supposed to be dependent on a common resource pool, the interaction between these functions remains relatively obscure (e.g. Wahle 1983). The accepted paradigm is that reproduction as well as growth and regeneration in corals are 'energy-costly' processes (reviewed in Rinkevich \& Loya 1989, Harrison \& Wallace 1990). Thus, there should be a trade-off in resource allocation between them, and injuries may lead to temporary or permanent shifts in energy allocation. It is widely agreed that sexual reproduction in corals is a highly sensitive life history characteristic which is easily disrupted during regeneration (Rinkevich \& Loya 1989). The decrease in reproductive activities, according to this idea, results from a limited amount of energy resources and the allocation of energy among various biological functions.

Several field studies support this idea. Kojis \& Quinn (1985) found lower fecundity in damaged Goniastrea fuvulus colonies, compared to intact controls, and suggested that this resulted from reallocation of limited energy resources to repair damaged tissue. Rinkevich \& Loya (1989) found that fecundity in regenerating colonies of Stylophora pistillata was an order of magnitude lower than in undamaged control colonies up to 19 mo after breakage. Van Veghel \& Bak (1994) studied regeneration versus reproduction in the Caribbean coral Montastrea annularis and found that the number of eggs in polyps adjacent to the regenerating lesions was significantly reduced. Relevant to the above studies is the argument that, among organisms frequently damaged as a result of physical circumstances, natural selection should favor repair/regenerative processes above other requirements (Karlson 1988).

The accepted paradigm of energy trade-off is based on controlled field studies. However, this does not necessarily mean that the interpretation is inevitably cor- 
rect. No study has yet identified how energy resources are channelled between the 'competing' biological functions nor how energy trade-offs are activated.

The enigma. Three unrelated lines of argument obtained from cnidarians critically challenge the above paradigm that reproduction and regeneration in damaged corals compete for the same limited amount of energy budget.

(1) Sexual reproduction in corals may not be subject to energy constraints. Although much evidence in the literature points to energy trade-off between sexual reproduction and various biological functions, other studies show that reproduction may also be expressed independently of energy constraints. This has been recorded in corals, in a variety of other cnidarians (Tardent 1985) and animals. For example, while growth rates of many coral species slowed down after the onset of sexuality (references cited in Chornesky \& Peters 1987), growth rates of female Porites astreoides colonies increased concurrently with the onset of sexual reproduction (Chomesky \& Peters 1987). Polyps of Monastrea annularis in mid-colony locations, including both fast-growing tips of knobs and slower-growing flat areas, displayed similar reproductive activity (Szmant 1991). Studies done on barnacles and fishes (reviewed in Roff 1992) further indicate that although sexual reproduction is a 'costly' biological function, it is sometimes independent of growth or body weight. In the same way, very small, sexually mature colonies of the ascidian Botrylloides sp., the remnants of larger colonies that had died, show no change in reproductive effort (Rinkevich et al. 1993).

Energy allocation to various biological functions in corals may be hierarchical (Harrison \& Wallace 1990) and programmed, where sexual reproduction may take precedence over other functions, such as growth and maintenance, or vice versa. Studies on corals have shown the effects of regeneration on reproductive activities (Kojis \& Quinn 1985, Rinkevich \& Loya 1989, Van Veghel \& Bak 1994), the effect of sexual reproduction on growth rates (Kojis \& Quinn 1981, 1985, Harrison \& Wallace 1990, Ward 1995), the effect of intraspecific competition on growth rates and reproduction (Rinkevich \& Loya 1985), and regeneration versus growth rate or pattern formation interrelationships (Kobayashi 1984, Meesters et al. 1994, KramarskyWinter \& Loya 1996). These studies may support the energy trade-off idea, but may also be intepreted as showing a preset hierarchy of biological functions.

(2) Shallow water scleractinians may not be prone to energy constraints. In reef building corals, sources for energy inputs are primarily photosynthates translocated by zooxanthellae and food particles captured by tentacles and cilia. The zooxanthellae translocate a variety of organic compounds to the host corals, pro- viding most of their energy requirements, including maintenance, tissue and skeletal growth, reproduction and also reserves (Muscatine \& Porter 1977, Muscatine et al. 1981, 1984, Rinkevich 1989). Consequently, corals may maintain high quantities of lipids in their tissues, either as structural or as storage materials, for a variety of purposes (Patton et al. 1977. Stimson 1987).

Much interest has been devoted to the energy interactions between zooxanthellae and the coral host. In shallow water branching coral colonies, Muscatine et al. (1984) found that the carbon translocated to the host was $>140 \%$ of its daily energy requirements. By using a different scientific approach, Davies $(1984,1991)$ and Edmunds \& Davies (1986) calculated for 5 reef corals that on a cloudless day the energy input of the translocated carbon is in excess of that required. Intake of zooplankton or particulate organic matter may increase the total diel carbon input. The surplus energy may be stored for future needs, which include reproductive activities (Rinkevich 1989, Harrison \& Wallace 1990) and repair. These results indicate the potential error of applying a general theory of energy trade-offs (Kozlowski \& Wiegart 1986, Roff 1992) to field observations on reproduction and regeneration in hermatypic corals. No study has, as yet, clearly documented that shallow water scleractinians are always prone to energy constraints, not even during regeneration. This conclusion does not hold for shallow water corals under chronic stress conditions (i.e. Szmant \& Gassman 1990, Allison et al. 1996).

(3) Regeneration is a regulated process, not related to energy trade-off. If regeneration is not an energylimited phenomenon, but is a 'preset' independent process, one may expect to detect events which are correlated only to the repair operation. Moreover, if regeneration does not deplete the coral's energy resources below some threshold, we may find cases where coral colonies are able to meet other demands during the regeneration process, such as growth and reproduction. Twelve such representative studies were employed on 1 medusa, 2 sea anemones, 2 gorgonians and 7 scleractinian corals (Table 1). In 3 studies, it was shown that energy constraint had no significant role in regeneration, and in 1 case such correlation was proposed. In 2 studies (Wahle 1983, Ward 1995; Table 1) reproductive efforts were clearly not correlated with energy trade-off for regeneration. In 6 studies, regeneration was proposed to be associated with or controlled by cellular elements (Young 1974, Lang da Silveira \& Van't Hof 1977, Patterson \& Landolt 1979, Wahle 1983, Lesh-Laurie et al. 1991, Kramarsky-Winter \& Loya 1996; Table 1). In 2 studies (Bak \& StewardVan Es 1980, Bak 1983; Table 1) the recovery of damaged tissue slowed down with time, a result which may indicate the depletion of resources other than energy 
Table 1 Representative list of studies on regeneration in the Scyphozoa and Anthozoa. Analysis of the results indicates that tissue repair is a complex and highly regulated process, not necessarily related to energy constraints. + means regeneration is controlled by cellular elements; na: no data available

\begin{tabular}{|c|c|c|c|c|}
\hline \multirow[t]{2}{*}{$\begin{array}{l}\text { Organism } \\
\text { studied }\end{array}$} & \multirow[t]{2}{*}{ Relevant results on tissue regeneration } & \multicolumn{2}{|c|}{$\begin{array}{l}\text { Evidence or proposed role } \\
\text { in regeneration for: }\end{array}$} & \multirow[t]{2}{*}{ Source } \\
\hline & & $\begin{array}{l}\text { Cellular } \\
\text { elements }\end{array}$ & $\begin{array}{l}\text { Energy } \\
\text { resources }\end{array}$ & \\
\hline $\begin{array}{l}\text { Aurelia } \\
\text { aurita }\end{array}$ & $\begin{array}{l}\text { Isolated tentacles regenerated, complete } \\
\text { polyps }\end{array}$ & + & No limitation & Lesh-Laurie et al. (1991) \\
\hline $\begin{array}{l}\text { Calliactis } \\
\text { parasitica }\end{array}$ & Influx of amoebocytes into the wound & + & na & Young (1974) \\
\hline $\begin{array}{l}\text { Anthopleura } \\
\text { elegantissima }\end{array}$ & $\begin{array}{l}\text { Wound repair starts with rapid influx of cells } \\
\text { derived from amoebocytes in the mesoglea }\end{array}$ & + & na & $\begin{array}{l}\text { Patterson \& Landolt } \\
\text { (1979) }\end{array}$ \\
\hline $\begin{array}{l}\text { Plexaura } \\
\text { homomalla }\end{array}$ & $\begin{array}{l}\text { Regeneration rate was independent of } \\
\text { either colony size or reproductive phase }\end{array}$ & Proposed & No limitation & Wahle (1983) \\
\hline $\begin{array}{l}\text { Plexaura } \\
\text { flexuosa }\end{array}$ & $\begin{array}{l}\text { Repeated injuries caused a decrease in } \\
\text { regeneration }\end{array}$ & + & na & $\begin{array}{l}\text { Lang da Silveira \& } \\
\text { Van't Hof (1977) }\end{array}$ \\
\hline $\begin{array}{l}\text { Pocillopora } \\
\text { damicornis }\end{array}$ & $\begin{array}{l}\text { Fragmented corals had no significant } \\
\text { change in growth rate or lipids but had } \\
\text { increased reproductive effort }\end{array}$ & na & No limitation & Ward (1995) \\
\hline $\begin{array}{l}\text { Porites } \\
\text { asteroides }\end{array}$ & $\begin{array}{l}\text { No influence on lesion regeneration, whether } \\
\text { it was positioned at the top or at the colony } \\
\text { side, where } 70 \% \text { less light was recorded }\end{array}$ & na & No limitation & Meesters et al. (1992) \\
\hline $\begin{array}{l}\text { Montastrea } \\
\text { annularis }\end{array}$ & $\begin{array}{l}\text { Regeneration is influenced by tissue bor- } \\
\text { dering the damaged area (lesion perimeter, } \\
\text { not lesion size or colony size) }\end{array}$ & na & Proposed & $\begin{array}{l}\text { Meesters et al. (1994) } \\
\text { and literature cited } \\
\text { therein }\end{array}$ \\
\hline $\begin{array}{l}\text { Acropora } \\
\text { palmata }\end{array}$ & $\begin{array}{l}\text { Recovery of damaged tissue slows down } \\
\text { with time }\end{array}$ & na & na & Bak (1983) \\
\hline $\begin{array}{l}\text { Agaricia agarici- } \\
\text { tes and Porites } \\
\text { astreoides }\end{array}$ & $\begin{array}{l}\text { Recovery of damaged tissue slows down } \\
\text { with time. This is a 'physiological char- } \\
\text { acteristic' of the corals }\end{array}$ & na & na & $\begin{array}{l}\text { Bak \& Steward-Van Es } \\
(1980)\end{array}$ \\
\hline $\begin{array}{l}\text { Fungia scutaria } \\
\text { and other } \\
\text { fungiid corals }\end{array}$ & $\begin{array}{l}\text { Mesenterial filaments which do no contain } \\
\text { all tissue elements fail to regenerate }\end{array}$ & Proposed & No limitation & $\begin{array}{l}\text { Krupp et al. (1993), } \\
\text { Kramarsky-Winter \& } \\
\text { Loya (1996) }\end{array}$ \\
\hline
\end{tabular}

or which may be a physiological characteristic of the repair process in corals (Bak \& Steward-Van Es 1980).

There are other studies which indicate that regeneration in corals is a complex and highly regulated process. In Acropora palmata, regeneration along a branch from tip to base at the first $25 \mathrm{~cm}$ was associated with tissue senesence (Meesters \& Bak 1995). In Goniastrea favulus, fragmented old colonies were more fecund than young colonies of the same colony size (Kojis \& Quinn 1985). Growth rates of Porites astreoides female colonies increased over the size range associated with the onset of reproduction, instead of decreasing (Chornesky \& Peters 1987). In fungiid corals (Kramarsky-Winter \& Loya 1996 and literature therein) coral fragments retaining part of the parental mouth regenerated around the original mouth and did not develop buds, as opposed to fragments isolated from the animals' periphery. These findings further indicate that basic biological functions in corals, such as regeneration, pattern formation, reproduction and growth, are characterized by 'preset' regulated processes that are not influenced directly through changes in other biological functions.

The proposed theorem. Cumulatively, the studies discussed above do not meet with the assumptions of the paradigm that regeneration and sexual reproduction in corals are related through energy trade-off. Several studies showed a reduction in reproductive activities during regeneration (Kojis \& Quinn 1985, Szmant-Froelich 1985, Rinkevich \& Loya 1989, Van Veghel \& Bak 1994, Ward 1995) and documented variations in reproduction related to localized regions of growth (Rinkevich \& Loya 1979, 1989, Oliver 1984, Heyward \& Collins 1985, Wallace 1985, Kojis 1986 , Harrison \& Wallace 1990). However, the studies discussed here (Kojis \& Quinn 1985, Chornesky \& Peters 1987, Meesters \& Bak 1995, and references in Table 1) may also suggest that, if there is any deprivation of a 
resource, reproduction and regeneration processes in normal, unstressed corals may be competing for something other than energy.

Growth, tissue repair and production of the germ cells require 1 major resource, the stem cells. The output of new and different types of cells, in the right numbers and at the right time, is central to the maintenance of the adult animal. One of the central issues in this field is the determination of the factors that regulate the activity of the stem cells. Commitment of progenitor cells to different types of somatic cells or to either soma or germ cells may also be influenced by environmental factors (Wolpert 1988). In regenerating planarian worms, male germ cells take part in blastema formation and are then capable of redifferentiating into somatic cells. The more mature male germ cells degenerate (literature cited in Gremigni et al. 1982). In the round worm Caenorhabditis elegans, a single cell located at the distal tip of each end of the gonad may prevent formation of sex cells. When it is destroyed, all nearby nuclei carry out meiosis and form gametes, irrespective of energy allocation (Austin \& Kimble 1987). In Hydra spp., germ and somatic cells are produced from the same stem cells (Tardent 1985), and environment rather than lineage plays the major role in determining the fate of stem cell progeny. Spatial variation in the distribution of various differentiated cell types is the consequence of local stem cell commitment (reviewed in Hall \& Watt 1989, Bode 1996).

The importance of stem cells in coral regeneration has already been discussed more than once. Lang da Silveira \& Van't Hof (1977) claimed that repeated cycles of injuries and regenerations in Plexaura flexousa can inhibit future regeneration by depleting a critical population of self-renewal stem cells. This idea was also discussed favorably by Wahle (1983), who examined the influence of regeneration on 3 Jamaican gorgonians and found that regeneration was independent of either colony size or reproductive phase. Szmant-Froelich (1985) proposed that gametogenesis and budding processes in corals may interact through competition for 'interstitial. cells', as was demonstrated in Hydra spp. (reviewed in Bode 1996). In at least 6 studies (Table 1), evidence for cellular elements in cnidarian regeneration was discussed.

While some studies have suggested that all cnidarian germ cells develop from interstitial cells (reviewed in Campbell 1974, Tardent 1985), many other studies indicate that true interstitial cells are missing in the Scyphozoa and Anthozoa. Amoebocytes, mainly in the mesoglea, serve as the stem cells (reviewed in Robson 1957. Chapman 1974, Young 1974, Larkman 1981, Fadlallah 1983) Since Scyphozoa and Anthozoa lack the extensive regenerative powers of the Hydrozoa with defined interstitial cells (reviewed in Young 1974), cases of regeneration in hydrozoans will not be discussed here

At least 2 studies, on Calliactis parasitica (Young 1974) and Anthopleura elegantissima (Patterson \& Landolt 1979), have recorded that wound repairs start with rapid influx of cells derived from amoebcytes in the mesoglea. However, no mitotic increase has been observed in the mesoglea or in the endoderm after wounding (Young 1974). This points to the route of differentiation of amoebocytes to ectodermal and endodermal cells, and to a pool (probably small) of reserved cells in the mesoglea that are available for immediate response. Thus we may re-analyze the results of Lang da Silveira \& Van't Hof (1977), who found that repeated injuries caused a decrease in regeneration in Plexaura homomalla, as the depletion of this pool of cells, and the results of Meesters et al. (1994), who found that regeneration in Montastrea annularis was influenced by the tissue bordering the damaged area, and not by lesion size or colony size, as the consequence of an available 'front line' for stem cell wandering. In a similar way, the results of Bak (1983) and Bak \& Steward-Van Es (1980), who recorded a slowdown with time in the recovery of damaged tissue in Acropora palmata, may be due to a depletion of reserve cells. The results of Meesters \& Bak (1995), who recorded that regeneration along a branch of A. palmata decreased significantly from tip to base, may be due to the accumulation of stem cells in the fast growing tip. The importance of cellular components in regeneration processes over shortage of energy resources was also demonstrated. In Aurelia aurita polyps, isolated tentacles are capable of regenerating whole new polyps by cell profileration and reorganization (Lesh-Laurie et al. 1991). In the solitary corals Fungia spp., fragments containing all cell types successfully regenerate, as opposed to fragments containing only endodermal cells (Krupp et al. 1993, KramarskyWinter \& Loya 1996).

In reef corals, therefore, there must be a reserve of cells able to migrate to wounds, to fast growing parts and to areas where germ cells are developed. These cells are also available to other basic biological functions, such as replacement of senescent cells and parasitic elimination. However, no high mitotic rate of these cells has ever been recorded (Young 1974, Lang da Silveira \& Van't Hof 1977, Patterson \& Landolt 1979). Any extensive use of those reserve cells (in repeated injuries, fast growth during regeneration, sexual reproduction with tissue repair, etc.) may reduce their numbers and significantly affect one or more of the other biological functions. A similar situation, termed 'exhaustion', was proposed for results in the mammalian system showing immune unresponsiveness to 
antigens that should elicit strong responses (Moskophidis et al. 1993, Rocha et al. 1995). Partial deletion of reactive immune cells temporarily reduces the animal's responsiveness to xenogeneic challenges.

The idea that under conditions of regeneration there is a conflicting demand for increasing the number of depleted stem cells versus increasing the rate of differentiation from stem cells is not new (Lajtha 1979) and the process of competition for precursor cells in Hydra spp. regeneration has recently been proposed (Müller 1995). Evidence in the literature has already pointed out that, as a result of such competition between stem and differentiated cells, the production of differentiated descendants becomes limited (Lajtha 1979). It is, therefore, proposed here that a trade-off for stem cells between tissue repair and sexual reproduction should be considered when we study changes in reproductive activities during regeneration in reef corals.

Acknowledgements. This study is part of the research done in the Minerva Center for Marine Invertebrate Immunology and Developmental Biology and was also supported by EC grant (INCO) no. ERB3514 PL950184. I thank U. Frank, N. Hall, T Hughes and H. M. Szmant for critically reading this paper.

\section{LITERATURE CITED}

Allison N, Tudhope AW, Fallick AE (1996) Factors influencing the stable carbon and oxygen isotopic composition of Porites lutea coral skeletons from Phuket, south Thailand. Coral Reefs 15:43-57

Austin J, Kimble J (1987) glp-1 is required in the germ line for regulation of the decision between mitosis and meiosis in C. elegans. Cell 51:589-599

Bak RPM (1983) Neoplasia, regeneration and growth in reef building coral Acropora palmata. Mar Biol 77:221-227

Bak RPM, Steward-Van Es Y (1980) Regeneration of superficial damage in the scleractinian corals, Agaracia agarIcites, F. purpurea and Porites astreoides. Bull Mar Sci 30: $883-887$

Bode HR (1996) The interstitial cell lineage of hydra: a stem cell system that arose early in evolution. J Cell Sci 109 $1155-1164$

Campbell RD (1974) Cniderla. In: Giese AC, Pearse JS (eds) Reproduction of marine invertebrates 1 Academic Press, New York, p 133-199

Chapman DM (1974) Cniderian histology. In: Muscatine L, Lenhoff HM (eds) Coelenterate biology, reviews and new perspectives. Academic Press, New York, p 2-92

Chornesky EA, Peters EC (1987) Sexual reproduction and colony growth in the scleractinian coral Porites astreoides. Biol Bull 172:161-177

Davies PS (1984) The role of zooxanthellae in the nutritional energy requirements of Pocillopora eydouxi. Coral Reefs $2: 181-186$

Davies PS (1991) Effect of daylight variations on the energy budgets of shallow-water corals. Mar Biol 108:137-144

Edmunds PJ, Davies PS (1986) An energy budget for Porites porites (Scleractinia). Mar Biol 92:339-347

Fadlallah YH (1983) Sexual reproduction, development and larval biology in scleractinian corals. A review. Coral Reefs $2: 129-150$
Gremignı $V$, Nigro M, Puccunelli I (1982) Evidence of male germ cell redifferentiation into female germ cells in planarian regeneration. J Embryol Exp Morphol 70:29-36

Hall PA, Watt FM (1989) Stem cells: the generation and maintenance of cellular diversity. cvDevelopment 106:619-633

Harrison PL. Wallace CC (1990) Reproduction, dispersal and recruitment of scleractinian corals. In: Dubinsky $Z$ (ed) Coral Reefs. Elsevier, Amsterdam, p 133-207

Heyward A.J, Collins JD (1985) Growth and sexual reproduction in the scleractinian coral Montipora digitata (Dana) Aust J Mar Freshwat Res 36:441-446

Karlson RH (1988) Size dependent growth in the zoanthid species: a contrast in clonal strategies. Ecology 69 : 1219-1232

Kobayashı A (1984) Regeneration and regrowth of fragmented colonies of the hermatypic corals Acropora formosa and Acropora masuta. Galaxea 3:13-23

Kojis BL. (1986) Sexual reproduction in Acropora (Isopora) species (Coelenterata: Scleractinia) I. A. cuneata and A. palifera on Heron Island reef, Great Barrier Reef. Mar Biol 91:291-309

Kojis BL, Quinn NJ (1981) Aspects of sexual reproduction and larval development in the shallow water hermatypic coral, Goniastrea australensis (Edwards and Haime, 1857). Bull Mar Sci 31:558-573

Kojis BL, Quinn NJ (1985) Puberty in Goniastrea favulus: age or size limited? Proc 5th Int Coral Reefs Congr 4:289-293

Kozlowski J, Wiegert RG (1986) Optimal allocation of energy to growth and reproduction. Theor Popul Biol 29:16-37

Kramarsky-Winter E, Loya Y (1996) Regeneration versus budding in fungiid corals: a trade-off. Mar Ecol Prog Ser 134 $179-185$

Krupp DA, Jokiel PL, Chartand TS (1993) Asexual reproduction by the solitary scleractinian coral Fungia scutaria on dead parent coralla in Kaneohe Bay, Oahu, Hawaiian Islands. Proc 7th Int Symp Coral Reefs 1:527-534

Lajtha LG (1979) Stem cell concepts. Differentiation 14:23-34

Lang da Silveira F, Van't Hof T (1977) Regeneration in the gorgonian Plexaura flexuosa (Cnidaria, Octocorallaa). Bijdr Dierk 47:99-108

Larkman AU (1981) An ultrastructural investigation of the early stages of oocyte differentiation in Actinia fragacea (Cnidaria: Anthozoa). Int J Invert Reprod 4:147-167

Lesh-Laurie GE, Hujer A, Suchy P (1991) Polyp regeneration from isolated tentacles of Aurelia scyphistomae: a role for gating mechanisms and cell division. Hydrobiologia 216/217:91-97

Meesters EH, Bak RPM (1993) Effect of coral bleaching on tissue regenerating potential and colony survival. Mar Ecol Prog Ser 96:189-198

Meesters EH, Bak RPM (1995) Age-related deterioration of a physiological function in the branching coral Acropora palmata. Mar Ecol Prog Ser 121:203-209

Meesters EH, Bos A, Gast GJ (1992) Effects of sedimentation and lesion position in coral tissue regeneration. Proc 7 th Int Coral Reef Symp 2:671-678

Meesters EH, Noordeloos M, Bak RPM (1994) Damage and regeneration. Links to growth in the reef building coral Montastrea annularis. Mar Ecol Prog Ser 112:119-128

Moskophidis D, Lechner F, Pircher H, Zinkernagel RM (1993) Virus persistence in actually infected immunocompetent mice by exhaustion of antiviral cytotoxic effector $T$ cells Nature 362:758-761

Müller WA (1995) Competition for factors and cellular resources as a principle of pattern formation in Hydra II. Assistance of foot formation by heads and buds and a new model of pattern control. Dev Biol 167:175-189 
Muscatine L, Falkowski PG, Porter JW, Dubinsky Z (1984) Fate of photosynthetic carbon in light and shade adapted colonies of the symbiotic coral Stylophora pistillata. Proc R Soc Lond B Biol Sci 222:181-202

Muscatine L, Mclosky LR, Marian RE (1981) Estimating the dally contribution of carbon from zooxanthellae to animal respiration. Limnol Oceanogr 26:601-611

Muscatine L, Porter JW (1977) Reef corals: naturalistic symbiosis adapted to nutrient poor environments. Bio Sci 27 : $454-460$

Oliver JK (1984) Intra-colony variation in the growth of Acropora formosa: extension rates and skeletal structures of white (zooxanthollae-free) and brown tipped branches. Coral Reefs 3:139-147

Patterson MJ, Landolt ML (1979) Cellular reaction to injury in the anthozoan Anthopleura elegantissima. J Invert Pathol 33: $189-196$

Patton JS, Abraham S, Benson AA (1977) Lipogenesis in the intact coral Pocillopora damicornis and its isolated zooxanthellae: evidence for a light derived carbon cycle between symbiont and host. Mar Biol 44:235-247

Rinkevich B (1989) The contribution of photosynthetic products to coral reproduction. Mar Biol 101:259-263

Rinkevich B, Loya Y (1979) The reproduction of the Red Sea coral Stylophora pistillata. II. Synchronization in breeding and seasonality of planulae shedding. Mar Ecol Prog Ser $1: 145-152$

Rinkevich B, Loya Y (1985) Intraspecific competition in a reef coral: effects on growth and reproduction. Oecologia 66: $100-105$

Rinkevich B, Loya Y (1989) Reproduction in regenerating colonies of the coral Stylophora pistillata. In: Spanier E, Steinberger $Y$, Luria $M$ (eds) Environmental quality and ecosystem stability, Vol IVB, Environmental Quality. ISEEQS Publ, Jerusalem, p 259-265

Rinkevich B, Shlemberg Z, Lilker-Levav T, Goren M, Fishelson L (1993) Life history characteristics of Botrylloides (Tunicata) populations in Akko Bay, Mediterranean coast of Israel. IsI J Zool 39:197-212

Robson EA (1957) The structure and hydrodynamics of the

This note was submitted to the editor musculo-epthelıum in Metridium. Quart J Microsc Sc1 98 $265-278$

Rocha B, Grandien A, Freitas AA (1995) Anergy and exhaustion are independent mechanısms of peripheral $T$ cell tolerance. J Exp Med 181:993-1003

Roff DA (1992) The evolution of life histories. Chapman and Hall, London

Stimson JS (1987) Location, quantity and rate of change in quantıty of lipıds in tıssue of Hawarian hermatypic corals. Bu.l. Mar Sci 41:889-904

Szmant AM (1991) Sexual reproduction by the Caribbean reef corals Montastrea annularis and $M$. Cavernosa. Mar Ecol Prog Ser 74:13-25

Szmant AM, Gassman NJ (1990) The effects of prolonged 'bleaching' on the tissue biomass and reproduction of the reef coral Montastrea annularis. Coral Reefs 8:217-224

Szmant-Froelich AM (1985) Reef coral reproduction: diversity and community patterns. In: Advances in reef science. University of Miami, FL, p 122-123

Tardent $P$ (1985) The differentiation of germ cells in Cnidania. In: Holvorson HO, Monroy A (eds) The origin and evolution of sex. Alan R Liss, New York, p 163-197

Van Veghel MLJ, Bak RPM (1994) Reproduction characteristics of the polymorphic Caribbean reef building coral Monastrea annularis. III. Reproduction in damaged and regenerating colonies. Mar Ecol Prog Ser 109:229-233

Wahle CM (1983) Regeneration of injuries among Jamaican gorgonians: the role of colony physiology and environment. Biol Bull 165:778-790

Wallace CC (1985) Reproduction, recruitment and fragmentation in nine sympatric species of the coral genus Acropora. Mar Biol 88:217-233

Ward S (1995) The effect of damage on the growth, reproduction and storage of lipids in the scleractunian coral Pocillopora damicornis (Linnaeus). J Exp Mar Biol Ecol 187:193-206

Wolpert L (1988) Stem cells: a problem in asymmetry. J Cell Sci Suppl 10:1-9

Young JAC (1974) The nature of tissue regeneration after wounding in the sea anemone Calliactis parasitica (Couch). J Mar Biol Ass UK 54:599-617

Manuscript first received: May 17, 1996

Revised version accepted: September 12, 1996 